Corporate Marketing: Apocalypse, Advent and Epiphany

This is a preprint (version of a paper accepted in its definitive form by Management Decision, () Professor John M.T.

Balmer. Email john.balmer@brunel.ac.uk and and has been posted by permission of Professor John M.T. Balmer for

personal use, not for redistribution. The article will be published in t Management Decision, Volume 47, No. 4: 544-572 (2009).

The definitive version of the paper can be accessed from: http://www.emeraldinsight.com/10.1108/00251740910959413

\title{
Corporate Marketing: Apocalypse, Advent and Epiphany
}

John M. T. Balmer

Professor of Corporate Marketing

Brunel University

London

\begin{abstract}
Purpose - this paper aims to explain the nature and relevance of corporate marketing and details the antecedents of the territory. Corporate marketing is a marketing and management paradigm which synthesises practical and theoretical insights from corporate image and reputation, corporate identity, corporate communications and corporate branding, among other corporate-level constructs.
\end{abstract}

Design/methodology/approach - via the adoption of a quadrivium; a traditional classical, four-part, approach to the acquisition of knowledge, I: (i) show how organisations can be faced by apocalyptical scenarios through a failure to accord sufficient attention to one or more dimensions of the corporate marketing mix, (ii) explain why the emergence of corporate level constructs such as corporate image, identity, branding communications and reputation represent, both individually and collectively, the advent of corporate marketing, (iii) detail the various integrative initiatives in corporate design, corporate communications and identity studies which, together with the incremental augmentation of the marketing philosophy find their natural dénouement in the epiphany of corporate marketing; (iv) describe the 6Cs of the corporate marketing mix and reflect upon possible future directions in organisational marketing.

Findings - paper reveals the efficacy of adopting an organisational-wide corporate marketing philosophy to management decision makers and scholars. Originality/Value - the practical utility of corporate marketing is explicated by making reference to case vignettes, and various marketing and non-marketing literatures

Practical Implications - drawing on the marketing/management theory of identity alignment policy advisors should accord attention to each dimension of the corporate marketing mix and ensure that they are in meaningful as well as in dynamic alignment. 
Paper type - Historical overview/literature review/case histories. This

Commentary is based on the opening remarks of the celebratory $10^{\text {th }}$ symposium of the International Corporate Identity Group (ICIG) held at Brunel University, London, in 2007.

Key words - corporate marketing, stakeholder marketing, corporate branding, corporate identity, Corporate communications, Corporate reputation, Coca-Cola 


\section{Corporate Marketing: Apocalypse, Advent and Epiphany}

\section{Introduction}

In this article, I scrutinise key developments in the fields of marketing and communications over the last half century beginning with the ascendancy of the corporate image construct in the 1950s; the rise of the corporate identity concept in the 1970s and, more recently, the importance attached to corporate branding. The above, along with other corporate-level constructs, the broadening of the marketing philosophy and integrative endeavours in design, communications and identity are, for me, key developments which underpin the nascent area of corporate marketing. In my paper, I detail the nature and importance of the corporate marketing philosophy. The approach adopted in this article is a highly personal one and I draw extensively on my own published work over the last two decades in this commentary.

In examining developments over the last two decades since the formation of the ICIG this opening article feels somewhat like an Apologia pro vita sua ("A defence of his own life").

The genesis of this paper is to be found in my opening remarks for the $10^{\text {th }}$ ICIG symposium. The structure of the paper draws on the canonical concepts of apocalypse, advent and epiphany and represents a journey from darkness to light. It is hoped that the corporate marketing mix and philosophy as detailed at the end of this commentary represents a transfiguration of marketing thought and will have a particular utility to management decision-makers and to the academy.

\section{Apocalypse: corporate marketing cataclysms}

Scrutinising the contemporary business environment, we can see that the strength of an organisation's identity, corporate brand, corporate communications and corporate reputation can give institutions a strategic advantage. The reverse is also true, i.e., weakness in these areas can be a disadvantage. This is because difficulties associated with the above zones can create hazardous vortices and currents that are not dissimilar to the travails inflicted by the celebrated four horsemen of the apocalypse. You may recall that the horsemen were characterised as harbingers of impending death and destruction. Consider the following, indicative, case vignettes from the recent, and not so recent, past: 
The Curious Case of Coca Cola -- Back in 1985, Coca-Cola, in one of the most celebrated product changes of recent times, adopted a new taste for the ubiquitous beverage, and introduced "New Coke" (Oliver 1986). Extensive consumer research had revealed a huge preference for the new taste of coke. Yet, on its launch, there was adverse public reaction to the new formula Coke that seemed to defy logic and which seemingly flew in the face of confirmatory and exhaustive marketing research; sales of the new Coca Cola slumped to apocryphal levels. Moreover, the corporation, along with its senior executives, came under fire. Coca Cola, it should be remembered, is both a corporate as well as a product brand and, therefore it was not surprising that the corporation's most senior executives, Roberto Goizueta (Chief Executive) and Donald Keough (President) were in the firing line and were denigrated by media and public alike. Feelings ran very high and, as reported in the Financial Times (Gapper 2008), one irate customer wrote to them and branded them, "The two dumbest executives in American history". In a dramatic volte face, senior executives soon reintroduced the classic Coca-Cola formula as "Coke Classic" as the sales of "New Coke" declined. Eventually the new formula drink was gradually phased out of production. What went wrong?

To me, two possible hypotheses for this apocalyptical scenario emerge from this case history.

First, it appears that management decision-makers did not appear to accord sufficient prominence to the duality of Coca Cola's brand identity as both a product and corporate brand. Moreover, to me, undue dependence was given to product-orientated marketing management initiatives whereas more reliance should have been accorded to the sphere of corporate marketing.

Second was the failure on the part of senior managers and their advisors to realise that Coca-Cola was a key, emblematic, US brand. By taking away the traditional taste they were, perhaps, seen by some to be removing a key icon of nation and people; it was, de facto, a national form of psychological amputation. What marketing research failed to take account of, it seems to me, was that Coca Cola was imbibed in two ways: as a much loved beverage, certainly, but also in a way that helped to define what it was to be American. In short, it addressed two key identity-based questions, namely: "Who are we?" and "What are we?" (Balmer 2008). To Americans, perhaps, Coca Cola was a constant, in a seemingly ever-changing world: a national commercial icon that was not entirely unlike the iconic status accorded to the British monarchy. The effect was not dissimilar to Coca Cola refashioning stars and stripes in a meaningfully different way. 
Ridiculous? In addition, decision-makers appeared to have marshalled product marketing research and management to an issue that had an important corporate implication and where a corporate marketing approach was equally apposite. Evidence from a neurological study which appeared in the medical journal Neuron was based on a clinical study of Coca Cola and Pepsi: this provided conclusive evidence that mental states changed when reference was made to the corporate and product brand name of Coca Cola, namely that mental states alter when reference is made to high-profile brand names and this includes Coca Cola (McClure et al 2004).

Of course, as marketing scholars have long known, cognitions affect behaviour. In addition, it is a sine qua non that icons of people and of nations are often perilous to change; when they are this must be undertaken with superlative care and sensitivity. It warrants note that "Classic Coke" adorned the Coca Cola bottles and cans until very recently and will be finally removed in the US in 2009.

A Transport of Fright to Delight: General Motors (GM) -- A failure to understand and to communicate your organisation's key identity traits is rather like driving at night without your lights on: you don't know where you are and you don't know where you are going; others don't know who you are and that you are there. Characteristically, a crash ensues and this can be cataclysmic. This scenario very much reflected the situation at General Motors (GM), during the 1920s when research commissioned by GM's legendary president, Alfred P. Sloan, Jr., revealed the shocking truth that although the corporation's car brands were well-known, General Motors as a company was virtually unknown: it lacked a corporate image (Marchand 1991). Realising that a time-bomb was ticking for the company if GM did not project its identity and build a corporate brand, Sloan embarked on what in my view was a series of corporate marketing initiatives relating to corporate identity, branding, communications and image. Research undertaken a decade latter in 1932 revealed a fulfilment of Sloan's ambitions as a very different picture emerged of the General Motors Corporation; not only was GM's identity well known but it had acquired a corporate brand identity that afforded considerable brand leverage in terms of consumer buying behaviour.

The Bitter Taste of Cadbury's Chocolate -- The turn of the $20^{\text {th }}$ Century was far from propitious for Cadburys, the eponymous English confectioner and chocolatière when in 1901 it was faced with particularly ruinous accusations that it was using African slave labour (Jeremy 1998 p. 553). The Cadbury dynasty 
smarted from the indictment since the scions of this family-owned company, as with their forebears, espoused philanthropic values grounded in their strict adherence to the Christian tenets of Quakerism. This appeared to be a prima facie case of what Harvard Business School Professor Stephen Greyser (1999) famously identifies as the "promise-performance" gap. The company's misery only intensified when the claims were finally corroborated after exhaustive investigations (which, it should be noted, took place over an extraordinary seven-year period). Fearing a public backlash and irreparable damage to Cadbury's reputation, the company and family sought to assuage public wrath by the extraordinary move of donating all profits accrued from 1902-1908 to charitable causes as a form of public corporate contrition. Providentially for Cadbury's the corporate brand still endures. Today, a seven-year inquiry would be viewed as gross procrastination and public abhorrence of such activities would, almost certainly, be of even higher apocryphal dimensions; it would probably be terminal in terms of the continuance of Cadbury's corporate brand. Corporations, of course, still encounter problems with their corporate reputations, and corporate brand reputations suffer as a result of problems associated with illegal and questionable activities of institutions and individuals in, or associated with, their supply chain.

As these case vignettes illustrate (see Exhibit One for recent case history examples), issues relating to corporate identity, branding, communications, image and reputation can have an apocalyptical quality and need to be at the forefront of the strategic deliberations. As the case histories reveal, institutional difficulties can be the result of the lack of alignment between key corporate level concerns; between reality (identity) and perception (image and reputation); between an espoused corporate covenant (the corporate brand) and reality(identity) and so on. The period from the 1950s to the present is one where practitioners and scholars have gradually appreciated the importance of individual corporate-level constructs and the complex relationships between and among them. To me, the strategic nature of the above is irrefutable.

\section{KINDLY TAKE IN EXHIBIT ONE AROUND HERE PLEASE THANK YOU.}

\section{Advent: corporate marketing antecedents}

In a canonical context, Advent is a time for preparation -- a period, in more general contexts, to contemplate key insights and texts of the past. Adopting a similar perspective to corporate marketing there is similar merit in scrutinising the historical evolution of the field. 
What is apparent is that for the last half-century or more a rich variety of corporate-level concepts have come to the fore, such as corporate image, corporate personality, corporate identity, corporate communications, corporate identity, and corporate branding.

A new gestalt of the corporation?

What seems to be implicit in all this a realisation that whereas many of the above corporate-level concepts are unquestionably of considerable importance, nonetheless they represent only part of a much broader gestalt. Both individually, and in their totality, they can be viewed as being precursors to a more integrated disciplinary and philosophical approach to management and which, for me, represent the advent of corporate marketing.

The various corporate-level constructs detailed above in my view provide the building blocks of corporate marketing. However, the outcomes of such developments are mixed.

On the positive side, we can see that each concept has spawned new zones of management; consultancy-based devotees; intellectual adherents; new/altered management theories as well as distinct literatures having their attendant publications; two indicative examples are Corporate Communications: An International Journal and its sister journal, Corporate Reputation Review. The various special editions of The European Journal of Marketing on corporate identity, corporate branding and corporate marketing dating back to 1997 are also of particular note. For me, each concept, however, is worthy of scrutiny in terms of being key antecedents of corporate marketing. What is evident is that the corporate-level concepts outlined earlier have thrown new light in comprehending as well as guiding the modern corporation: these insights are potentially of considerable benefit to senior executives.

Alas, the summative outcomes of these developments have not entirely been propitious, which I attribute to what I call the "magnetism of monomania". The latter occurs where one concept is held in particular affection at any one particular time by a group of scholars and/or practitioners; this occurs in part because the particular concept reflects the Zeitgeist and, more significantly perhaps, mirrors the prevailing management fad within the territory.

For instance, for some, corporate branding has entirely replaced corporate identity as an area of consultancy and scholarship. Quite often, there is not a scintilla of difference between the writing on corporate branding and that 
relating to corporate identity. Curiously, when scrutinising the historiography of the field it is curious to note that some of those who blew the trumpets at corporate identity's nativity are now seemingly firm adherents of a corporate identity eschatological cult.

However, I am of the firm view that both constructs are of critical importance in comprehending and revealing the modern corporation.

The hotel sector is a case in point. Quite often, when you stay at a hotel having a well-known global brand name you are quite likely to be experiencing three entity types. The corporate brand name can be owned by one institution while the hotel property is owned by another corporation (franchising is widespread within the sector). Moreover, the running of hotel may have been contracted out to another company. Today, the InterContinental corporation is called "assetlight" since it owns only 16 of its 4,186 branded properties (The Economist 2009). In addition, InterContinental owns other well-known brand names such as Crowne Plaza and Holiday Inn. The situation can be even more complicated where there is dual ownership of a corporate brand: Hilton was a case in point. As such, it is imperative that senior executives manage their corporate brands and identities so that they are meaningfully aligned (Balmer and Thomson 2009).

From my analysis of developments over the last half-century it is clear that a conceptual life cycle seems to have characterised the field. For instance, particular concepts can be seen at one time to have been in the ascendant, have then achieved a short-lived hegemony and then have lost something of their allure and sheen: corporate image, corporate personality, corporate identity and house style are indicative examples.

I continue this section by briefly detailing what I see to be the key insights in the development of corporate marketing over the last half century. Initially, practitioners and scholars looked up the corporate marketing telescope and focused on corporate image and the importance of organisational perception. More recently, these groups looked down the telescope to focus on the roots of corporate image, reputation, and corporate communications; as such increased importance was accorded to revealing an organisation's defining traits: what I here call corporate identity. The perspective adopted here both draws from and builds on my work relating to the historiography of corporate marketing (Balmer 1998, 2001, 2008).

(a) 1950-1970: the hegemony of corporate image: the power of perception 
Since time immemorial, images have been at the heart of philosophical thought, as the theories of Aristotle, Plato, Locke, Hume and John Stuart Mill testify.

In business contexts, the period from the 1950s to the 1970s resulted in an upsurge of interest in the concept of the corporate image, in large part as a consequence of the book "The Image" penned by the English economist Kenneth Boulding (1956), the activities of the Opinion Research Corporation (ORC) in the USA, the work of Burleigh Gardner of Social Research Inc., (USA) and the writings of Pierre Martineau $(1958,1958 a)$ who undertook numerous corporate image studies for the Chicago Tribune. Other literature on the concept is also of note (Bristol 1960; Boorstein 1961; Spector 1961; Riley 1963; Schafhauser 1967; Crissy 1971; Bernays 1977; Kennedy 1977; Gray and Smeltzer 1985; Dowling 1986, 1993; Abratt 1989; Grunig 1993; Gray and Balmer 1998; Gotsi and Wilson 2001).

In the 1960s, the formation of MORI in Great Britain by corporate image consultant Sir Robert Worcester led to analogous activities to those of ORC; his writing, and corporate image research undertaken by MORI, have also been especially influential (Worcester 1986; 1997). His article in this special edition represents another, highly significant, contribution to the genre.

The corporate image literature stresses the importance of perception, particularly the fact that perceptions materially affect behaviour and that we respond to images in the same way as we do to reality. Corporate images can vary between individuals and between different interest groups, and images can inhabit different time frames (past, current and future-orientated perception) and can be erroneous, inequitable, and whimsical as well as good, bad or even non-existent as the early example of General Motors showed. A good deal of the writing stresses the importance of image management; however these early writings do not always make the key distinction between the organisation as a transmitter of images and stakeholders as receivers of images (Balmer and Greyser 2003).

\section{(b) 1970s-early 1980s: unearthing the identity of corporate identity}

Identity represents another venerable construct. Since the mists of time many of the great themes of intellectual inquiry are related to identity and it has a prominent position in philosophical discourse as the work of Armstrong, Feigl and Place attest. Moreover, scientific inquiry, according to Passmore, at its essence is concerned with the unearthing of identities (Balmer 2008). 
Just as in the past scholars have been concerned with issues relating to individual, collective, juridical and national/cultural identities, it is not surprising that it should surface, as it did with vengeance in the 1970s and 1980s, as a key organisational concern, and thus corporate identity emerged as a critical corporate-level construct.

Today a multitude of meanings are accorded to the corporate identity concept (Balmer 1995, 2008; Cornelissen et al 2007; He and Balmer 2007). However, two dominant perspectives inform the area. As such, corporate identity refers to an organisation's innate attributes as well as to the deployment of graphic design to to convey an institution's actual or desired identity. The former perspective tends to inform academic writing on the territory whereas the latter underpins a good deal of the work undertaken by practitioners.

The most influential and enduring writing on the area has, arguably, undertaken by two corporate identity panjandrums: the US practitioner, Walter Margulies (1977) and the English identity consultant Wally Olins (1978, 1978a). Also of note is the pioneering work of the English consultant Pilditch (1971) and the influential tome of F.H.K. Henrion - of Henrion, Ludlow and Schmidt consultancy fame - and the Cambridge mathematician Alan Parkin (Henrion and Parkin 1967).

At its essence, this graphic design view of corporate identity relates to the effective use of an organisation's trademark. A variety of outcomes are claims made for the effective use of such marques, the most significant being the creation of a favourable corporate image. So-called, corporate identity manuals detail what, how and where the trademark should be used. A trade mark is the legally-protected defining mark of an entity. Heraldry and the Laws of Heraldry represent a much earlier manifestation of what, today, we would call trademark law. In 1960, Paul Rand, the legendary US graphic designer penned the following summary of how trademarks work. It has become a definitive exposition of this important graphic design concern (In Aynsley 2004. p.108),:

"A trademark is a picture. It is a symbol, a sign, an emblem, an escutcheon, an image. A symbol of a corporation, a sign of the quality, blend, form and content. Trademarks are animate, inanimate, organic, geometric. They are letters, ideograms, monograms, colours, things. They indicate, not represent, but suggest and are stated with brevity and wit".

Margulies is credited with coining the corporate identity concept in 1964 and defined it along the following lines: "that component of a corporation's image that 
can be wholly controlled by a company", (Balmer and Greyser 2003 p. 67). However, the introduction of the concept caused not inconsiderable exasperation and confusion. For instance, the celebrated English-based consulted F.H.K. Henrion lamented the introduction of the concept and the demise of the term House Style that was in common parlance in Britain and elsewhere. He felt that House Style construct more accurately captured the graphic design roots and activities of the area.

A somewhat more cerebral approach to corporate identity was adopted by Wally Olins $(1978 ; 1978 a)$ in his various disquisitions on the territory. Olins had the intuition to realise that identity had a number of meanings in that: (a) it relates to how an organisation presents itself to its stakeholders via visual identification, (b) relates to what an organisation is, what it does, and how internal (organisational) cultures emerge and support identity and (c) the way an organisation presents itself to the world via a multitude of communication channels directed at external and internal publics.

Of especial note was Olins reliance on corporate identity principles to affect changes in company cultures. His work with London's police force is a case in point (Olins 1991).

In recent years, like so many of those within the graphic design industry, Wally Olins has embraced the corporate branding construct and increasingly disregards the corporate identity concept. This is not unlike corporate identity's eclipse of the term House Style.

Today, the corporate identity concept engenders not inconsiderable interest from scholars.

From the early 1990s onwards, marketing and communications scholars began to explore the corporate identity concept. Since then, various literature reviews have attempts to capture the various characterisations of corporate identity (Balmer 1995, 1998, 2001; Van Riel and Balmer 1997; Alessandri 2001; Cornelissen and Harris 2001).

Balmer's (1995) initial analysis identified seven schools-of-thought relating to corporate identity. The three, non graphic design, schools stress that corporate identity can be strategic, cultural (behavioural) or promotional (corporate communications) in nature. The remaining four schools note the importance of graphic design in articulating an organisation's strategy, culture and 
communications. It was also noted that graphic design is used to keep a corporation's visual identity fashionable. Van Riel and Balmer (1997) synthesised the above viewpoints to three. For their part, Cornelissen and Harris (2001) concluded that the literature characterises corporate identity as an expression of corporate reality, as an expression of corporate personality and as a concept that is equated with all expressions emanating from a corporation. Balmer (2001) offered 15 reasons why 'fog' surrounds the corporate identity construct and argued that the corporate identity mix encompassed strategy, structure, communication and culture whilst the corporate identity management mix required the consideration of stakeholders, reputations and the environment in addition.

From the above analyses, two broad characterisations of corporate identity emerge. Both viewpoints inform some anthologies and articles on the territory (VanRiel and Balmer; Balmer and Greyser 2003; Melewar 2008).

The first viewpoint views corporate identity in terms of an organisation's defining characteristics (Balmer and Wilkinson 1991; Balmer 2001; Cornelissen et al 2007). It embraces a multidisciplinary perspective and is informed by legal, economic and stakeholder viewpoints of contemporary organisations (Balmer 2008).

The second perspective views corporate identity in terms of an institution's concern in projecting the current or aspirational identity to its stakeholders via visual means (VanRiel 1995; Alessandri 2001; 2008).

The following definitions illustrate the two notions of corporate identity cited above:

"An organisation's identity is a summation of those tangible and intangible elements that make any corporate entity distinct. It is shaped by the actions of corporate founders and leaders, by tradition and the environment. At is core is the mix of employees' values which are expressed in terms of their affinities to corporate, professional, national and other identities. It is multidisciplinary in scope and is a melding of (past) strategy, structure, communication and culture. It is manifested through multifarious communications channels encapsulating product and organisational performance, employee communication and behaviour, controlled communication and stakeholder and network discourse". (Balmer 2001 p.280) 
"Organisational identity is the strategically planned and purposeful presentation of an organisation. This includes all the observable and measurable elements of an organisation's identity manifest it is comprehensive visual presentation, including-but not limited to- its name, logo, tagline, colour-palette, and architecture". (Alessandri 2001; 2008).

(c) mid 1980s-mid 1990s: an episode of three. The advent of (i) corporate communication, (ii) corporate reputation, and (iii) parallel disciplinary insights from social identity, organisational identity and stakeholder theory

(i) corporate communications

David Bernstein and Professors Cees Van Riel and Stephen Greyser are arguably among the pioneers of a field of marketing and management that became known as corporate communications. Pride of place surely belongs to a prominent English communications and advertising consultant, who in 1984 published a book that was to have important reverberations in what, as a field of management, became known as corporate communications. David Bernstein's book, Company Image and Reality: A Critique of Corporate Communications, highlighted the importance of corporate communications and the strategic necessity for senior executives to adopt an overarching corporate-wide communications programme which adopted a stakeholder perspective; his famous corporate communications wheel affords a highly practical framework for managers (Balmer and Greyser 2003 p.141). Senior executives, he argued, have a duty to communicate with their customers, stakeholders, to their industry and, moreover, and importantly, to society in general. As Bernstein's insightful article in this special edition reveals, senior managers all too often fail in this regard.

Seemingly inspired by Bernstein's disquisition, the Dutch scholar Van Riel (1995) penned what is arguably the first academic textbook on the territory: it too was influential. He argues that the three distinct strands of corporate communication require orchestration: management communication (having an employee focus); marketing communication (having a customer focus) and organisational communication (having a stakeholder focus).

Stephen A. Greyser, the legendary Harvard Business School Professor, conceived and developed what is considered the first corporate communications course to be offered by a leading business school in the mid-1980s. As a teacher he has done a great deal to advance the importance of corporate communications, 
including his case study work, to several generations of Harvard MBA's; many are senior decision-makers in the corporate world.

Today, the field of corporate communications has a number of distinguished advocates of the territory, including Kitchen and Schultz (2001), Cornelissen (2004) and Argenti et al (2005).

The absence of a well-defined and managed corporate communications strategy which reveals an organisation's purposes, philosophy, and intentions to customers and stakeholders can result in communications, and resultant images, that are diffuse, confusing, contradictory, inchoate and sometimes prolix in addition.

\section{(ii) corporate reputation}

Arguably, it has been the work of the noted US scholar, Charles Fombrun (Fombrun and Shanley 1990; Fombrun 1996), who has propelled the corporate reputation construct to the centre stage. This being the case, one should not lose sight of the seminal tome by Bromley dating back to 1993 which provides a comprehensive overview of the field. Although corporate image is, to me (viz: Gray and Balmer 1998), a parallel, closely related but nevertheless distinct concept, the advent of the corporate reputation construct has meant that it has in some quarters replaced reference to the corporate image. Fombrun and Van Riel (1998) analyse the concept from economic, strategic, marketing, organisational, sociological as well as accounting perspectives. Fombrun and Rindova (1996) usefully define corporate reputation along five dimensions and conclude that reputations are (a) historically rooted; (b) of saliency to external and internal publics; (c) based on former (corporate) activities and achievements; (d) evaluated in terms of the benefits derived by a stakeholder group; and (e) enable the organisation to stand out from others in its sector or sectors. Since the publication of Fombrun's work many other scholars have expanded our knowledge of the concept: a good deal of this work appears in the journal Corporate Reputation Review. In addition, the reputational rankings of institutions in publications such as Fortune, the Financial Times, Asian Business and the Far Eastern Economic Review are illustrative of the saliency as well as importance accorded to the construct by policy-makers in global contexts.

Other pertinent literature on corporate reputation has been penned by Bennett and Kottasz (2000); Bromley (1993, 2002); Bronn (2007); Dowling (2001, 2004); Gray and Balmer (1998); Greyser (1999); Davis et al (2002); and Grunig (1993). 
The corporate associations construct is also of note. Introduced by work of Brown and Cox (1997) and Brown and Dacin (1997), the concept relates to the information that an individual has about a particular entity. In essence, it is an umbrella construct which encompasses both the corporate image and corporate reputation constructs.

(iii) parallel disciplinary insights from social identity, organisational identity and stakeholder theory

Another important development in the territory has been the recognition, by marketing scholars, of the theoretical and conceptual advances relating to social identity theory, an area which mainly is informed by research grounded in social psychology (viz: Tajfel 1972; Tajfel and Turner 1979; and Haslam and Ellemers 2005). Social identity theory explains the phenomenon of an individual's alignment to a social grouping; this theory has been drawn on by organisational behaviorists to explain group affinity in corporate contexts (Ashforth and Mael 1989) which shed light on the phenomenon of individuals aligning themselves to a social group; or being regarded by others as a member of such a group.

Also of note, and again taking an employee perspective, was the seminal work of Albert and Whetten (1985) that introduced the concept of organisational identity. They explained that it referred to the claims of an organisation's employees related to what they viewed was an organisation's defining traits in terms of attributes that were (a) central, (b) distinctive and (c) enduring.

The issue of stakeholder identification with the organisation has emerged as an important line of inquiry within both the management and marketing canons; limited space for this commentary means that a detailed examination of these developments cannot be undertaken here. However, for a considered examination of employee identification see Dutton et al (1994) and Pratt (1998); for customer identification see Bhattaracharya and Sen (2003). With regard to social identity theory vis a vis corporate brand identity, the perspectives offered by the "Latin School of Thought" in marketing is noteworthy; it is based on the view that marketing management should, in part, be focused on the creation of social ties between and among individuals where a person's membership of a corporate brand community or tribe is coveted above the consumption of products and services (Badot and Cova 1995).

To summarise, the corporate identity construct is increasingly informed by the view that organisations have recognisable institutional traits. In contrast, the 
organisational identity construct is based on employees' cognitions of an organisation's defining traits.

Corporate identity is informed by economic, juridical and stakeholder theories of organisations. This identity paradigm views institutions as entities that are tangible, distinct, and divisible from other identity types. The parallel construction of organisational identity is informed by the theoretical viewpoint that institutions are socially constructed entities. This perspective considers that organisations can only be comprehended from the perspective of organisational members as part of a group collective. For a more thorough examination of the above literatures from a British, European and Commonwealth perspective see Cornelissen et al (2007). For an excellent overview of US perspectives on the territory see Brown et al (2006).

The notion that institutions should have a stakeholder focus rather than a somewhat narrower shareholder or customer foci has been an influential development and informs the corporate marketing perspective elucidated here. It was Freeman's (1984) landmark publication, Strategic Management: A Stakeholder Perspective, that outlined the basic principles of stakeholder theory and management. Other, important publications on this territory include Mitchell et al (1997) explanation of which stakeholders count and why; usefully they present a framework for the prioritisation of stakeholders.

\section{(d) mid 1990s: corporate branding makes its marque and heralds the advent of corporate marketing}

From the mid-1990s onwards, the corporate branding construct has enjoyed heightened prominence among other corporate level concepts (viz: Balmer 1995, 2001b; Balmer and Thomson 2009; Balmer et al 2009; Ind 1997; Harris and deChernatony 2001; Balmer and Gray 2003; Knox, and Bickerton, 2003; Schultz and Hatch 2003; Urde 2003; Urde et al 2007; Lawer and Knox 2008; Merrilees and Miller 2008; Mukherjee and Balmer 2008; Leitch and Devenport 2008; Ohnemus and Jenster (2008).

The theoretical underpinnings of corporate branding are still in their adolescent but a number of theoretical perspectives have been advanced in the literature (Mukherjee and Balmer 2008; Leitch and Devenport 2008; Ohnemus and Jenster 2008). Balmer (2001) avers that a corporate brand identity represents a distillation of key corporate identity attributes which he sees as a corporate form of biogenesis. Over time, these attributes by design and or evolution become a 
series of expectations and associations that become associated with the corporate brand name and or marque; these customer/stakeholder expectations represent an informal contract between the corporate brand and its stakeholder community. Balmer views the corporate brand identity as a distinct identity category; a not-dissimilar approach characterises the work of Urde (2003) who identifies different levels of corporate brand values that are meaningful. Mats Urde draws on, and develops, his considerable scholarship in this territory in the penultimate article of this special edition.

Within the canon there seems to be a broad consensus that corporate brands are best understood as systems of meaning rather than as tangible objects. Further, it has been noted that corporate brands have multiple organisational associations such as Virgin Atlantic, Virgin Trains, Virgin Records etc. and the extensive franchise arrangements of organisations such as McDonald's and the Body Shop (Balmer 2001; 2001b and Leitch and Richardson 2003). I argue that legal ownership of a corporate brand is vested with one or more entities, emotional ownership (and thereby its substantive value) resides with those who 'consume' the institutional brand.

\section{Epiphany: manifestation of a philosophy of corporate marketing}

The Solemnity of the Epiphany celebrates the apogee of the revelatory journey undertaken by Caspar, Melchior, and Balthazar; these three wise men of the East, according to tradition, were guided by the iridescent light of a star to their appointed destiny. In this, the final section of this commentary, I detail the Epiphany of Corporate Marketing, an area that I have been treating both individually and collectively for the last decade or so (Balmer 1998, 2001; Balmer and Greyser 2003) and which, recently, appears to have generated not inconsiderable interest (Balmer and Greyser 2006).

In advancing my hypothesis of corporate marketing I explain that it is based on the view that it is a manifestation of an organisational-wide philosophy and one which, importantly, has an explicit stakeholder as well as a customer orientation. It is based on my conceptualisation of corporate marketing as nothing short of being a new gestalt of the corporation, a supra-organisational philosophy that embraces the key organisational and management zones of corporate identity, corporate branding, corporate image and reputation, corporate communications, corporate culture and, of course, stakeholder management.

Before introducing the Corporate Marketing Star (below), I detail my understanding of the area's genesis. This, I believe is part of a venerable 
integrationist tradition which has characterised design (integrated design), communication (integrated corporate communications) and, finally, identity (the integration of identity-based views of the corporation). These developments are detailed in Appendix One.

As explained in Balmer (2001) and Balmer and Greyser (2006), corporate marketing may be viewed as a logical development in terms of practitioner and scholarly characterisations of marketing. I believe that a cardinal error of those who write about marketing is the failure to realise that marketing (and therefore corporate marketing) is at its foundation a philosophy.

A means of advancing, as well as operationalising, this territory is my sexpartite corporate marketing mix (the '6Cs' of Corporate Marketing), shown in diagrammatic form as a star. My first corporate marketing mix (Balmer 1998) has subsequently been simplified to form the 6Cs as outlined here (see Balmer 2006; Balmer and Greyser 2006).

To me, there are three substantive differences that distinguish the corporate marketing mix from the traditional marketing mix:

1. The elements of the mix are broader

2. The traditional mix requires a radical reconfiguration from product/services marketing

3. The mix elements have distinct disciplinary traditions

The elements of my corporate marketing mix are shown in the form of a sexpartite star (see Exhibit Two).

\title{
KINDLY TAKE IN EXHIBIT TWO AROUND HERE PLEASE. THANK YOU
}

\author{
EXHIBIT TWO
}


CULTURE

"What we feel we are"

\section{Balmer's Corporate Marketing Mix \\ CHARACTER \\ "What we indubitably \\ are"}

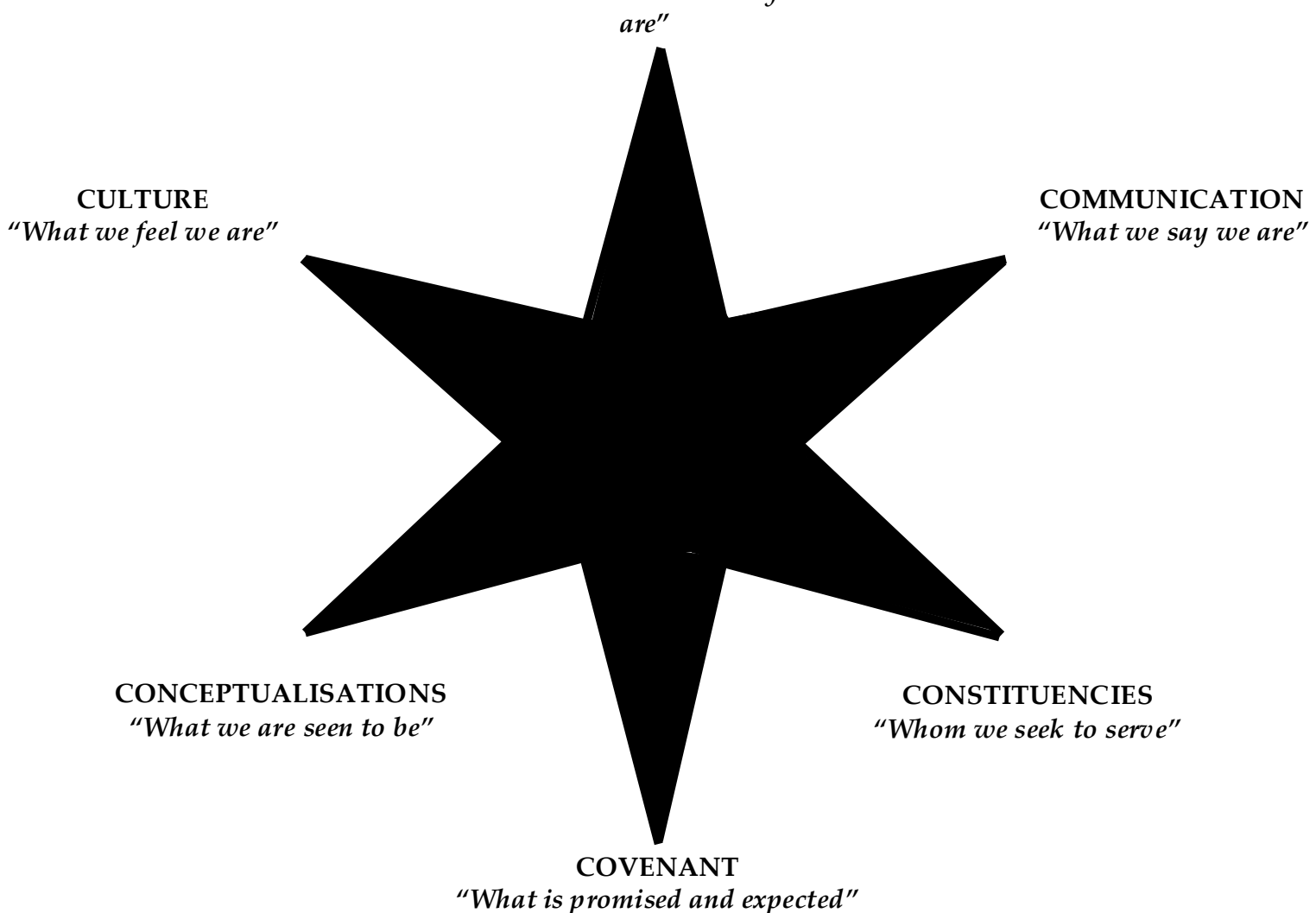

Balmer (2006)

The following section provides a brief description of each of the six corporate marketing mix elements and includes the roots of the mix element (for instance character is informed by insights from corporate identity scholarship). There is also a key question that underpins each facet of the mix: it is a question intended to be of assistance to senior policy-makers within contemporary organisations.

\section{CHARACTER}

Key Question:" What are the distinctive and defining institutional traits of our organisation?"

Key Concept: Corporate Identity

Organisational traits are those elements that define or meaningfully differentiate one entity from another: legal constitution - such as mutual, company, charity, corporation, co-operative etc., -- organisational activities, markets served, corporate ownership and structure, organisational type, corporate philosophy and corporate history etc.). 


\section{CULTURE}

Key Question: "What are the collective feelings of employees towards their organisation?"

Key Concept/s: Organisational Identification and Corporate Culture

These beliefs are derived from the values, beliefs, and assumptions about the organisation and its historical roots and heritage. Culture provides the context in which staffs engage with each other and with other groups such as customers: employees represent the "front-line" of the organisation. Organisational identification encapsulates organisational members' collective cognition of an entity's defining identity traits.

\section{CONSTITUENCIES}

Key Question: "Which stakeholders are of critical importance to the organisation and why?"

Key Concept/s: Stakeholder Theory and Corporate Governance

The philosophy of corporate marketing is predicated upon the fact that the continuance, and success, of organisations entail meeting the wants and needs of a variety of stakeholder groups: customers are of course (in most instances) of primary importance. Without the support (and identification) of such groups for and with the entity the organisation might not have a marketplace license to operate. Corporate Marketing should also come with a realisation that individuals can belong to several stakeholder groups (as a customer, employee, shareholder and so on). Stakeholder management may, in broad terms, be viewed as analogous to the comprehension of the importance of a corporation's "constituencies". My conceptualisation of stakeholders is somewhat broader to that found elsewhere since it may also embrace a concern with past as well as future organisational constituencies (Balmer 2001. p.283). This is especially the case with regard to mutuals, co-operatives, charities and partnerships (the John Lewis Partnership is a case in point).

\section{CONCEPTUALISATIONS}

Key Question: "How are we seen by are key stakeholders?"

Key Concept: Corporate Image and Corporate Reputation

Perceptions (conceptualisations) held of the organisation by individuals and stakeholder groups can materially affect their sense of association with an organisation/and or corporate brand and are likely to have an impact on behaviour. Corporate image represents the immediate mental picture an individual has of an organisation whereas corporate reputation is the result of 
facts, beliefs, images and experiences encountered by an individual over time. Corporate image and corporate reputation, of course, interpenetrate.

\section{COMMUNICATION}

Key Question: "Who do we say we are and to whom do we say this?"

Key Concept: Corporate Communications

Corporate communications relates to the totality of controlled messages from the organisation directed towards customers, employees and stakeholders.

\section{COVENANT}

Key Question: "What are the distinct components that underpin our corporate brand covenant (corporate brand promise???)

Key Concept: Corporate Brand

A corporate brand is akin to a contract (albeit one that is informal but is nevertheless powerful) and relates to the associations/brand promise that a brand name evokes. As such it can be compared to a corporate covenant. Corporate brands are derived from a particular corporate identity at one point in time and as such corporate brand values are a synthesis of key values inherent within the identity. Whereas (I hold) legal ownership of a corporate brand is vested in an entity its emotional ownership (and therein its substantive value) resides with those who have a close association with the brand. A failure to keep the corporate brand covenant (the promise that is associated with a particular brand by customers and other stakeholders) is a very serious sin and can affect the identity and reputation of the organisation.

\section{Caveat}

Two additional dimensions require attention in terms of the corporate marketing mix: context and custodianship.

Context refers to those supra-and subordinate corporate mix elements that impinge on the corporate marketing mix (identities, reputations and brand identities of nations, suppliers, industries. alliances etc.) along with the impact of the political, economic, ethical, social, and technological environment.

Custodianship refers to the key custodial role of senior management in relation to the mix (corporate marketing as with corporate brand management should be a board-level concern). For instance, in orchestrating the mix, senior executives (taking identity as an indicative example) may be guided not only by strategic insight but by their own, firmly held, vision. They might also ignore troublesome facts and developments and alter their cognitive state as a result and as a 
consequence this might place undue reliance on the trappings rather than substance of organisational change such as the adopting of a new visual identity.

\section{Aligning the corporate marketing mix elements}

The corporate marketing star aims to provide senior executives with the key components that in my estimation inform the corporate marketing paradigm. However, it will be noted that the six elements of the star are broadly symmetrical and, as such, such an approach should characterise the relationships among the six elements which should be broadly calibrated. Senior executives should not aim for rigid alignment across the elements: such an approach is probably not attainable and, if the elements were firmly coupled, this could be potentially hazardous. The aim should be for management decision makers to strive for the elements to be in broad, but also dynamic alignment: this is because identities are always in the making and are never finally made. A simple fourstage approach can inform the analytical and management process that should underpin the process of alignment; it is called the REDS process (see: Balmer and Soenen 1998; Balmer 2001a):

R Reveal key data relating to each corporate marketing mix element

E Examine the relationship across the elements for misalignments

D Diagnose which alignments require management intervention

S Select a strategy in order to achieve dynamic calibration

\section{Conclusion}

In reflecting on developments over the last half-century in the territory that has become corporate marketing, it is clear that considerable progress has been made in terms of our general comprehension of a variety of corporate-level constructs along with the relationships among them. Whilst in recent years we have witnessed important theoretical work in explicating the nature of the area, we should not lose sight that the organisational concepts examined here are, and should be, of strategic importance to management decision-makers in contemporary organisations. We need to look no further for "evidence" than the case vignettes relating to Coca Cola, General Motors and Cadburys, among others, earlier in this article.

Since the first symposium of 1994 the environment has changed. Back then at the first and subsequent ICIG symposia there was considerable enthusiasm for the corporate identity construct and some scepticism about my analysis which led me to conclude that corporate brands would grow in importance as an area of 
management and scholarship: see "Corporate Branding and Connoisseurship" (Balmer 1995).

Today, the tables have turned and primary attention is now accorded to corporate branding and the importance of comprehending and managing it. Analysing other corporate-level zones of marketing is all too often disregarded: this is another example of monomania. To me, this can lead to organisational difficulties of apocalyptical proportions.

I often think of a swimming pool as an appropriate metaphor for the above phenomenon. Invariably, most of the noise and activity take place in the shallow end of the pool. It is there that most of the children are to be found and only when the sun shines.

Another attendant concern of mine in the 1990s was the efficacy of integrating key corporate-level concepts and the logic of adopting a corporate marketing philosophy: see "Corporate Identity, Corporate Branding and the Advent of Corporate Marketing" (Balmer 1998). Its apogee has yet to come. However, I believe that the case for integrating key corporate-level constructs and activities is now irrefutable as well as overdue.

In this opening article, it is my hope that I have practiced what I preach. Past and present students of mine may remember two Balmerisms. The first relates to an espoused modus operandi of mine, namely that "the cerebral needs to be married with the practical". To me, theoretical and academic insights are of vital importance in that they advance our knowledge of an area. However, they have an additional value since when the cerebral is married with the practical, then there can be real meaning. Similar values mirror the philosophical basis of this journal and the papers which comprise this special edition celebrating the work of the ICIG. It is my hope that the journey we have undertaken in this opening article provides a useful context and exegesis of the perspectives offered by leading authorities in this special edition. Of course, the approach adopted in this commentary is analogous to the relationship between the Greeks and the Romans: leading with ideas rather than power. However, as Isaiah Berlin mused, we should not underestimate the power of ideas (Hardy 2000. p. ix).

Another Balmerism relates to a favourite modus vivendi of mine, namely one espoused by the bon mot "It is better to catch flies with wine rather than with vinegar". Certainly, there is much good wine in this special edition; wine that should be sipped slowly and that merits several tastings. 
Per ardua ad astra

In bringing this short commentary to a close, and in reflecting on developments in the area, it sometimes feels as if those in field are sometimes not unlike the dor ha-midbar, the Biblical generation who wandered for forty years in the desert.

The papers selected for publication in this special edition are certainly illuminating, and all of my fellow contributors do, of course, have stellar reputations.

Real meaning can be attained when managers have a route-map a guiding light. Managers might, perhaps, take heed of the inspirational motto of Britain's Royal Air Force "per ardua ad astra," which translates as "through difficulties to the stars". This is not unlike the journey we have taken in this article.

Perhaps, as with the three wise men, we can find light in the darkness. It is my hope that the corporate marketing star affords a meaningful way forward for scholars and decision makers and alike. Be guided by the Star.

\section{EXHIBIT ONE}

CORPORATE MARKETING APOCALYPSE. SOME RECENT CASE HISTORIES

Sour Milk from China's Sanlu Group and spicing up the books at India's Satyam Computer Services

It was a company that was proud of its espoused corporate philosophy which was emblazoned outside its corporate headquarters: "Quality and safety are the foundations of social harmony". Yet, in recent times its milk-based products have killed four infants and have made a further 6,000 seriously ill. The organisation is the Sanlu Group based in Shijiazuang, China. Known for its milk powder brands, it has scandalised much of China with revelations that it had knowingly sold contaminated milk powder via the bulking out of product with water mixed with a potentially lethal chemical (The Economist 2008). Turning to the Indian subcontinent, in early 2009 the chairman and company founder of one of India's largest services and software corporations, Satyam Computer Services, confessed that he, along with his brother, had 'cooked' the company's books, and confessed 
to a $\$ 1.47$ billion fraud. To add insult to injury the company name when translated from Sanskrit into English means "truth". (The Economist 2009a).

Qantas: the airline brand that boomeranged

Famously, it was the celebrated comment uttered by Dustin Hoffman in the film the "Rain Man" that identified the airline as the safest in the world with his aside that "Qantas never crashed" (Canning 2008). This seemingly was the genesis for the airline's implicit and explicit espousal of safety as one of its key corporate branding traits. For instance, former corporate advertising campaigns have dwelt on pilots' uniforms and on engine cowlings which carried the Rolls Royce brand marque in order to reinforce subtly one of the carrier's key brand values: safety. In 2008 a series of events beset Qantas, including a major incident where one of its aged 747s effected an emergency landing in Manila after an oxygen flask exploded, causing a gaping hole in the airline's fuselage; this episode caused a good deal of public and media consternation and was, no doubt, apocalyptical news for policy-makers at the airline. As Steve Parsons, Federal Secretary of the Australian Licensed Airline Engineers Association remarked: "I think (the brand) is irrevocably damaged right now", and continued, "It will take a long time for it to be held so far above any other airline". (Canning 2008). Although it takes years to establish an enviable corporate brand reputation it can very quickly be damaged and even destroyed: fortuitously for Qantas only the former seems to apply.

\section{Banking on Corporate Communication or Corporate Hallucination?}

The corporate brand slogans of erstwhile financial institutions after the virtual collapse of the financial services sector in 2008, now make for curious reading; many have a hollow, if not slightly droll, quality: "You can count on us". (Indy Bank); "The strength to be there". (American International Group). Other financial institutions proclaimed their organisation's raison d'etre via their corporate advertising, which now has a decidedly ironic twist: " $(A)$ lender that actually finds ways to make loans". (Countrywide); "As the American dream grows, so do we". (Fannie Mae). In Europe, the corporate communications of certain financial institutions now, in retrospect, seen to have a foreboding and perhaps ironic quality: "Here today, where tomorrow?" (Fortis); "The short term has no future".(Dexia) (The Economist 2008a).

\section{Adopting the brace position following cabin crew commentary}

The rise of social networks such as Twitter, Facebook and MySpace has been an unmitigated corporate marketing catastrophe for two British airline carriers, Virgin Atlantic (VA) and British Airways (BA). Both BA and VA personnel have posted derogatory comments about their own companies and passengers. For 
instance, VA staff have used the euphemism "chavs" to describe those British passengers having questionable taste and manners and, in a similar vein, BA crew have also posted complaints that passengers could be bothersome and sometimes malodorous as well; VA personnel teased that planes were infested with cockroaches. Passengers were not amused (The Economist 2008b).

Greyser's article on brand crises in this collection additionally describes and analyses several situations from the contemporary business environment.

\section{APPENDIX ONE}
ANTECEDENTS OF CORPORATE MARKETING: INTEGRATED DESIGN, INTEGRATED CORPORATE COMMUNICATION AND INTEGRATION OF IDENTITY-BASED VIEWS OF THE FIRM

Integrated Design

The efficacy of design/architectural integration and coordination so that a unified design gestalt can be realised which reflects an espoused corporate ethos has been a feature of organisational life since time immemorial. Significant manifestations of the phenomenon can be found within the early religious orders of the Catholic church (viz: the Carthusians, Benedictines, and Franciscans) and, more recently, in the early $19^{\text {th }}$ Century with regard to the great railway and shipping corporations of Great Britain, the USA, Canada and Continental Europe: Brunel's Great Western Railway (GWR), Cunard and the Peninsular and Oriental Steam Navigation Company $(\mathrm{P} \& \mathrm{O})$ are cases in point.

As Sir John Betjeman observed in his book London's Historic Railway Stations notes:

"The individuality of the great (railway) companies was expressed in styles of architecture, typography and liveries of engines and carriages, even down to the knives and forks and crockery used in refreshments rooms and dining cars".

(Olins 1978. p. 19)

In 1861 what became known as the Arts and Crafts Movement was established in England by Burne-Jones, Rossetti and Morris who advocated an elevated position for design along with the breaking down of the barriers between design and the manufacturing process. The movement was especially influential on the world stage and was greatly influenced by the pioneering work and philosophy of John Ruskin (Mackenzie 2001). The movement may perhaps be viewed as progenitor to the pioneering work of Peter Behrens at AEG and Adriano Olivetti at Olivetti in the early $20^{\text {th }}$ Century with regard to integrated design/architecture and that of the Wiener Werkstatte. 
Of particular note is the enduring legacy of integrated design (including graphic design) and architecture bequeathed by Frank Pick for London Transport/London Underground. He viewed London's transport system in a unified visual scheme that coordinated architecture and design. His legacy endures today as the new typeface created by Edward Johnston in 1916. Also of note is the iconic circle and bar symbol of London Transport. Henry Beck's map of the London underground system is another enduring design.

The establishment of the Movimento Comunita by Behrens and Olivetti took design integration to new heights and was, in addition, underpinned by an ethic that organisations had broader societal and stakeholder responsibilities that should take priority over profit maximisation.

More recently, the advent of graphic design consultancy/consultancies have further promoted the efficacy of design integration and have given particular prominence to organisations having a unified system of visual identification. In Great Britain was known as an organisation's House Style and eventually and perhaps confusingly, was called corporate identity by Margulies in the US (viz: Lippincott and Margulies 1957; Henrion and Parkin 1967; Blake 1971; Pilditch 1971, 1976; Selame and Selame 1975; Olins 1978, 1978a).

\section{Integrated Corporate Communication}

Since the late 1970s a number of debates have taken place relating to the integrated communications which have variously focused on the integration of marketing communications functions (Meffert 1979); the integration of marketing communications and public relations (Kotler and Mindak 1978); and, more recently, the integration of all communications functions (Aberg 1990).

Two notable strands of thought emerged from these deliberations which variously focused on (i) integrated marketing communications (Knecht 1989; Schultz et al 1991) and (ii) integrated corporate communications (Bernstein 1984; Van Riel 1995). It was these two authors, a consultant (Bernstein) and an academic (Van Riel), who made important inroads with regard to elucidating the importance of integrating organisational-wide communications.

Christensen et al (2008) provide a reproach to those who in advancing the case for integrative communications stress rigidity rather than flexibility in their approach: the same admonishment is equally apposite for the other integrative endeavours detailed here. In closing this short overview of integrative corporate 
communications, it seems indubitably to be the case that the onset of the integrative corporate communications paradigm represents a critical milestone in what I see as the corporate marketing odyssey.

Integration of Identity-based Views of the Corporation

A final integrative trend has been one in relation to identity studies in corporate contexts. Although marketing scholars and others have long advocated the efficacy of adopting a multidisciplinary perspective towards identity studies, it has been only over the last few years that significant progress has been achieved by (a) detailing the different strands of thought in marketing and management vis a vis management studies and (b) beginning the task of explaining the links among these diverse identity perspectives and thus developing an integrationist schema (Balmer 1995, 2008; Balmer and Soenen 1999; Balmer and Greyser 2002, 2003; Brown et al 2006; Cardador and Pratt 2006; Cornelissen et al 2007; He and Balmer 2007). The review by Cornelissen et al (2007), for instance, observed that in recent years the marketing and corporate communications literatures have begun to overlap (viz: Van Riel and Balmer 1997) and went on, in part, to detail some, but not all, of the principal schools of thought relating to social identity, organisational identity and visual identity/corporate identity.

Recent reviews have examined the corporate identity construct vis a vis the literature on organisational identity and social identity (Brown et al 2006; Cornelissen et al 2007; He and Balmer 2008; Balmer 2008).

\section{The Theory of Identity Alignment}

Within marketing, the importance of aligning image with identity has a venerable provenance (viz: Kennedy 1977). The genesis of this approach is to be found in both the practitioner (Diefenbach 1982; Bernstein 1984) and academic literatures (Abratt 1989; Balmer 1995). All stress the strategic significance of the corporate identity/corporate image interface. Moreover, they also pronounce the efficacy, indeed necessity, for senior executives to take account of an organisation's defining corporate identity traits, and they caution against having an over-reliance on corporate communications campaigns and the use of visual identification schemes as part of corporate image-building initiatives.

Balmer $(1998 ; 2001 a)$ went on to aver that although the importance of the corporate image/corporate identity interface is irrefutable, it was in addition a strategic imperative for organisations to attain alignment at multiple levels and among key identity types: as such, this represented what is in effect a nascent theory of identity alignment. Balmer (1998) both individually and 
collaboratively (viz: Cornelissen et al 2007) argued that it was an organisational imperative to attain alignment among a variety of interfaces and explained that a variety of sub-optimal outcomes could result, including customer, employee and stakeholder indifference, as well as displeasure and disengagement on the part of customers, stakeholders, and industry partners. Moreover, identity miscalibration could result in corporate atrophy and, in extremis, corporate cessation. The efficacy of calibrating different institutional identity types resulted in Balmer's ACID Test model which has undergone a number of developments and refinements (Balmer and Soenen 1999, Balmer 2001a, Balmer and Greyser 2002; Balmer et al 2009). The last version of Balmer's model includes corporate brand identity which, to the author, is a distinct identity type (see Balmer in Balmer and Greyser p.252 and Balmer et al 2009). The five identity types are as follows: actual identity (an organisation's defining traits), communicated identity (the identity that is communicated via graphic design and corporate communications), conceived identity (the perceived identity from stakeholder, customer and employee perspectives), covenanted identity (the corporate brand identity/brand promise), ideal identity (the future strategicallyorientated identity) and desired identity (the future-orientated identity that lives in the hearts and minds of senior decision makers).

Among scholars who have written on corporate identity per se (and do not necessarily focus on identity alignment) see: Abratt (see: Abratt 1989; Bick et al 2003); Alessandri (Alessandri 2001; Alessandri and Alessandri 2004); Ashman (Ashman and Winstanley 2007); Atakan (Atakan and Eker 2007); Baker (see: Baker and Balmer 1997); Balmer (see: Balmer 1994, 1995, 1998, 1997; Balmer and Wilkinson 1991; Balmer and Wilson 1998; Balmer et al 2007); Bendixen (Bendixen and Abratt 2007); Berrone (Berrone et al 2007); Brown and Dacin (see: Brown et al 2006); Christensen (Christensen and Akergaard 2001); Cornelius (Cornelius et al 2007); Cornelissen (Cornelissen and Elving 2003); Dinnie (see: Balmer and Dinnie 1999, 1999a; Fukukawa (Fukukawa et al 2007); Greyser (see: Balmer and Greyser 2002, 2003); He (see: He and Balmer 2007, 2007a; Leitch and Motion (1999); Marwick (Marwick and Fill 1997); Melewar (see: Melewar 2001; Melewar et al 2000, 2001, 2002; Melewar and Harold 1999; Melewar and Jenkins 2002; Melewar and Karaosmanoglu 2006); Simoes. Dibb and Fisk (2005); Stuart (1999); Taguiri 1982; Topalian (1984) and Van Riel (see: Van Riel and Balmer 1997); Wilkinson (Wilkinson and Balmer 1996).

\section{References}


Aberg, L. (1990) "Theoretical model and praxis of total communications", International Public Relations Review, Vol. 13, No. 2, pp. 13-16.

Abratt, R. (1989) "A new approach to the corporate image management process", Journal of Marketing Management, Vol. 5, No. 1, pp. 63-76.

Albert, S.B.E., and Whetten, D. (1985) "Organizational identity", In Cummings, L.L. and Staw, B.M. (eds) Research in Organizational Behavior, Vol. 8. JAI Press, Greenwich, pp. 263-295.

Alessandri, W.S. (2008) Non-traditional expressions of organizational visual identity: reaching consumers through alternative means. In Melewar, T.C. (ed) Facets of Corporate Identity, Communication and Reputation, Routledge, London.

Alessandri, W.S. (2001) "Modeling corporate identity: a concept explication and theoretical examination", Corporate Communications: An International Journal, Vol. 6, No. 2, pp. 173-182.

Alessandri, W.S., and Alessandri, T. (2004) "Promoting and protecting corporate identity: the importance of organizational and industry context", Corporate Reputation Review,Vol. 7, No. 3, pp. 252-268.

Argenti, P.A., Howell, R.A., and Beck, K.A. (2005) "The strategic communications imperative", MIT Sloan Management Review, pp. 83-89.

Ashforth, B.E., and Mael, F. (1989) "Social identity theory and the organization", Academy of Management Review, Vol. 14, pp. 20-39.

Ashman, I., and Winstanley, D.. (2007) "For or against corporate identity? Personification and the problem of moral agency", Journal of Business Ethics, Vol. 76, No. 1, pp. 83-95.

Atakan, M.G.S., Eker, T. (2007) “Corporate identity of a socially responsible university-a case from Turkish higher education sector", Journal of Business Ethics, Vol. 76, No. 1, pp. 55-68.

Aynsley, J. (2004) Pioneers of Modern Graphic Design. AComplete History, Octopus Publishing, London. 
Badot, O., and Cova, B. (1995) "Communuate et consommation: prospective pour un marketing tribal", Revue Francaise du Marketing, Vol. 1, No 151, pp. 5-17.

Baker, M.J., and Balmer, J.M.T. (1997) “Visual identity: trappings or substance?" Special Edition on Corporate Identity: European Journal of Marketing. Vol. 5 and 6, No. 3, pp. 366-382.

Balmer, J.M.T. (2008) “Identity based views of the corporation: insights from corporate identity, organisational identity, social identity, visual identity and corporate image", European Journal of Marketing, Vol. 42, No. 9-10, pp.879-906.

Balmer, J.M.T. (2006) "Comprehending corporate marketing and the corporate marketing mix", Bradford University School of Management, Working Paper Series, No. 06/08.

Balmer, J.M.T. (2005) Corporate Brand Cultures and Communities in Schroeder, J.E., and Salzer-Morling, M. (Eds) Brand Culture, Routledge, London. pp. 34-49.

Balmer, J.M.T. (2002) "Of identities lost and found", International Studies of Management and Organizations, Vol. 32, No. 3. pp. 10-27.

Balmer, J. M. T. (2001). "Corporate identity, corporate branding and corporate marketing - seeing through the fog", European Journal of Marketing, Vol. 35, No. 3 and 4, pp.248-291

Balmer, J.M.T. (2001a) "From the pentagon: a new identity framework", Corporate Reputation Review, Vol. 4, No. 1, pp. 11-22.

Balmer, J.M.T. (2001b) “The three virtues and seven deadly sins of corporate brand management", Journal of General Management, No. 27, No. 1, pp.1-17.

Balmer, J.M.T. (1998) "Corporate identity and the advent of corporate marketing", Journal of Marketing Management, Vol. 14, No. 8, pp. 963-996.

Balmer, J.M.T. (1997) "Corporate identity: What is it? What of it? and What is next?" Corporate Reputation Review, Vol. 1, No 2, pp. 183-188.

Balmer, J.M.T. (1995) "Corporate branding and connoisseurship", Journal of General Management, Vol. 21, No. 1, pp. 2-46. 
Balmer, J.M.T. (1995a) "Corporate identity: the power and the paradox", Design Management Reviewl, Vol. 6, No.1, pp. 15-26.

Balmer, J.M.T. (1994) "The BBC's corporate identity: myth, paradox and reality", Journal of General Management, Vol. 19, No 3, Spring, pp.33-49.

Balmer, J.M.T., Stewart, H., and Greyser, S.A. (2009) "Corporate brand and identity alignment: the strategic positioning of British Airways in the $20^{\text {th }}$ Century", California Management Review, (in press)

Balmer, J.M.T., and Thomson, I. (2009) "The shared management and ownership of corporate brands", Journal of General Management, Vol. 34, No. 4, Summer. (in press).

Balmer, J.M.T., Fukukawa, K., and Gray, E.R. (2007) "The nature and management of ethical corporate identity: a commentary on corporate identity, corporate social responsibility and ethics", Journal of Business Ethics, Vol. 76, No. 1. pp. 7-15.

Balmer, J.M.T., and Greyser, S.A. (2006) "Corporate marketing: integrating corporate identity, corporate branding, corporate communications, corporate image and corporate reputation", European Journal of Marketing, Vol. 40, No. 7 and 8, pp. 730-741.

Balmer, J.M.T., and Gray, E. (2003) "Corporate brands: what are they? What of them?" European Journal of Marketing, Vol. 37, No. 7-8, pp. 972-997.

Balmer, J.M.T., and Greyser, S.A. (2003) Revealing the Corporation. Perspectives on Identity, Image, Reputation, Corporate Branding and Corporate-Level Marketing, Routledge, London.

Balmer, J.M.T., and Greyser, S.A. (2002) "Managing the multiple identities of the corporation", California Management Review, Vol. 44, No. 3, pp. 72-86.

Balmer, J.M.T., and Soenen, G. (1999) "The ACID test of corporate identity management", Journal of Marketing Management, Vol. 15, No. 1-3, pp. 69-92.

Balmer, J.M.T., and Dinnie, K. (1999) "Merger madness: the final coup de Grace", Journal of General Management, Vol. 4, No. 4, pp.171-176. 
Balmer, J.M.T., and Dinnie, K. (1999a) "Corporate identity and corporate communications: the antidote to merger madness", Corporate Communications: An International Journal, Vol. 4, No. 4, pp. 182-192.

Balmer, J.M.T., and Wilson, A, (1998) "Corporate identity: it is more than meets the eye", International Studies of Management and Organizations, Vol. 28, No. 3, pp.12-31.

Balmer, J.M.T., and Wilkinson. A. (1991) "Building societies: change strategy and corporate identity", Journal of General Management, Vol. 1-17, No 2, Winter, pp. 20-34.

Bendixen, M., and Abratt, R. (2007) "Corporate identity, ethics and reputation in supplier-buyer relationships", Journal of Business Ethics, Vol. 76, No. 1, pp. 69-82.

Bennett, R., and Kottasz, R. (2000) "Practitioner perceptions of corporate reputation", Corporate Communications: An International Journal, Vol. 5, No. 3 pp. 224-234.

Bernays, E. (1977) “Down with image, up with reality", Public Relations Quarterly, Vol. 22, No. 1, pp. 12-14.

Bernstein, D. (1984) Company Image and Reality: A Critique of Corporate Communications, Holt, Rinehart and Winston, Eastbourne, UK.

Berrone, P., Surroca, J., and Tribo, J.A. (2007) "Corporate ethical identity as a determinant of firm performance: a test of the mediating role of stakeholder satisfaction", Journal of Business Ethics, Vol. 76, No. 1, pp. 35-53.

Bhattacharya, C.B., and Sen, S. (2003) "Consumer-company identification: a framework for understanding consumer's relationships with companies", Journal of Marketing, Vol. 67, pp.76-88.

Bick, G., Jacobson, M.C., and Abratt, R. (2003) "The corporate identity management process revisited", Journal of Marketing Management, Vol. 19, pp. 835-855.

Boorstein, D. (1961) The Image, Pelican, Gretna, LA.

Boulding, K. (1956) The Image, University of Michigan Press, Ann Arbor. 
Blake, J.E. (ed) (1971) A Management Guide to Corporate Identity; Lund Humphries, London.

Bristol, L.H. (1960) Developing the Corporate Image: A Management Approach to Public Relations, Scribner, New York.

Bromley, D. (1993) Reputation, Image and Impression Management, John Wiley, Chichester.

Bromley, D. (2002) “Comparing corporate reputations: league tables, quotients, benchmarks and case studies", Corporate Reputation Review, Vol. 5, No. 1, pp. 3550 .

Bronn, P.S. (2007) "Relationship outcomes as determinates of reputation", Corporate Communications: An International Journal, Vol. 12, No. 45, pp. 376-393.

Brown, T.J., Dacin, P.A., Pratt, M.G., and Whetten, D.A. (2006) "Identity, intended image, construed image and reputation: an interdisciplinary framework and suggested terminology", Journal of The Academy of Marketing Science, Vol. 34 No. 2, pp. 99-106.

Brown, T.J., and Cox, E.L. (1997) "The company and product: corporate associations and consumer product responses", Corporate Reputation Review, Vol. 1, No. 1 and 2, pp. 34-38.

Brown, T.J., and Dacin, A. (1997) "The company and the product: corporate associations and consumer product responses", Journal of Marketing, Vol. 61, January, pp. 68-84.

Canning, S. (2008) "Flying into turbulence", The Australian, Monday 11, p.28.

Cardador, M.T., and Pratt, M.G. (2006) “Identification management and its bases: bridging management and marketing perspectives through a focus on affiliation dimensions", Journal of The Academy of Marketing Science, Vol. 34, No.2, pp 174184.

Christensen, L.T., Firat, A.F., and Torp, S. (2008) “The organisation of integrated communications: toward flexible integration", European Journal of Marketing, Vol. 42, No. 3 \& 4, pp. 423-452. 
Christensen, L.T., and Askergaard, S. (2001) "Corporate identity and corporate image revisited", European Journal of Marketing, Vol. 31, No. 5 \& 6, pp. 292-316.

Cornelissen, J.P. (2004) Corporate Communications: Theory and Practice, Sage, London.

Cornelissen, J.P., Haslam, S.A., and Balmer, J.M.T. (2007) “Social identity, organisational identity and corporate identity; towards an integrated understanding of processes, patternings and products," British Journal of Management, Vol. 18, pp.1-16.

Cornelissen, J.P., and Elving, W.J.L. (2003) “Managing corporate identity: an integrative framework of dimensions and determinants", Corporate Communications: An International Journal, Vol. 8, No. 2, pp. 114-120.

Cornelissen, J.P., and Harris, P. (2001) "The corporate identity metaphor: perspectives, problems and prospects", Journal of Marketing Management, Vol. 17, pp. $49-71$.

Cornelius, N., Wallace, J., and Tassabehji, R. (2007) "An analysis of corporate social responsibility, corporate identity and ethics teaching in business schools", Journal of Business Ethics, Vol. 76, No. 1, pp. 117-135.

Crissy, W.J. (1971) “Image: what is it?” MSU Business Topics, Winter, pp. 77-80.

Davies, G., Chun. R., DaSilva, R. and Roper, R., (2002) Corporate Reputation and Competitiveness, Routledge, London.

Diefenbach, J.M. (1982) “Design as a management tool: the strategic thinking about the design process," unpublished paper delivered at the Design Management Institute Conference, Boston, December 9-10.

Dowling, G.R. (2004) “Corporate reputations: should you compete on yours?" California Management Review, No. 46, No. 3, pp. 19-36.

Dowling, G.R. (2001) Creating Corporate Reputations: Identity, Image and Performance, Oxford University Press, Oxford. 
Dowling, G.R. (1993) "Developing your corporate image into a corporate asset", Long Range Planning, Vol. 26, No. 2, pp. 101-109.

Dowling, G.R. (1986) “Managing your corporate images", Industrial Marketing Management, Vol. 15, No. 2, May.

Dutton, J.E., Dukerich, J.M., and Harquail, C.V. (1994) “Organizational images and member identification", Administrative Science Quarterly, Vol. 39, No. 2, pp. 239-263.

The Economist. (2009) "Outsourcing as you sleep”. February 21. p.69

The Economist. (2009a) “Corporate governance. India's Enron”. January 10. p.58

The Economist. (2008) "Formula for disaster", September 20 p. 69-70

The Economist. (2008a) “Bank slogans: ad nauseam”, October 4, p.92.

The Economist. (2008b) "Companies and social networks: losing face", November 8. p. 82.

Fombrun, C.J. (1996) Reputation: Realizing Value from the Corporate Image, Harvard University Press. Cambridge, MA.

Fombrun, C.J., and Shanley, M. (1990) “What's in a name? Reputation building and corporate strategy", Academy of Management Journal, Vol. 33, pp. 233-258.

Fombrun, C.J., and Rindova, V., (1996) “Who's tops and who decides? The social construction of corporate reputations", Working Paper, Stern School of Business, New York University.

Fombrun, C.J., and Van Riel, C.B.M. (1998) "The reputational landscape", Corporate Reputation Review, Vol. 1, No. 1, pp. 5-13.

Freeman, R.E. (1984) Strategic Management: A Stakeholder Approach, Pitman, Boston, MA. 
Fukukawa, K., Balmer, J.M.T., and Gray, E.R. (2007) "Mapping the interface between corporate identity, ethics and corporate social responsibility", Journal of Business Ethics, Vol. 76, No. 1, pp. 1-5.

Gapper, J. (2008) "Thou shalt not tell the unsweetened truth", Financial Times, (Business Life), July 24, p. 10.

Gotsi, M., and Wilson, A. (2001) "Corporate Reputation: seeking a definition", Corporate Communications: An International Journal, Vol. 6, No. 1, pp. 24-30.

Gray, E.R., and Balmer, J.M.T. (1998) “Managing corporate image and corporate reputation", Long Range Planning, Vol. 31, No. 5, pp. 695-702.

Gray, E.R., and Smeltzer, L.R. (1985) "Corporate image: an integral part of strategy", Sloan Management Review, Vol. 26, No. 4, pp. 73-48.

Greyser, S.A. (1999) "Advancing and enhancing corporate reputation", Corporate Communications: An International Journal, Vol. 4, No. 4, pp. 177-181.

Grunig, J. (1993) "Image and substance: from symbolic to behavioral relationships", Public Relations Review, Vol. 19, No. 2, pp. 121-139.

Hardy, H. (ed) (2000) Isaiah Berlin: The Power of Ideas, Chatto and Windus, London.

Harris, F., and deChernatony, L. "Corporate branding and corporate brand performance", European Journal of Marketing, Vol. 35, No. 3 and 4, pp. 441-456.

Haslam, S.E., and Ellemers, N. (2005) "Social identity in industrial and organizational psychology: concepts, controversies and contributions", International Review of Industrial and Organizational Psychology, Vol. 20, pp. 39-118.

Hatch, M-J., and Schultz, M. (eds) (2004) Organizational Identity, Oxford University Press, Oxford.

He, H-W., and Balmer, J.M.T. (2007) "Identity studies: multiple perspectives and implications for corporate level marketing", European Journal of Marketing, (in press).

He, H.W., and Balmer. J.M.T. (2007a) “Managerial perceived identity/strategy 
Dissonance: triggers and managerial responses", Journal of General Management, Autumn, Vol.33, No. 1, pp.71-91.

Henrion, F., and Parkin, A. (1967) Design Co-ordination and Corporate Image, London, Studio Vista.

Ind, N. (1997) The Corporate Brand, Kogan Page, London.

Jeremy, D.J. (1998) A Business History of Britain. Oxford University Press, Oxford.

Kennedy, S. (1977) "Nurturing corporate images", European Journal of Marketing, Vol. 11, No. 3, pp. 120-164.

Kitchen, P., and Schultz, D.E. (eds) (2001) Raising the Corporate Umbrella; Corporate Communications in the $21^{\text {st }}$ Century, Palgrave, Basingstoke.

Knecht, J. (1989) Geintegreerde Communicatie, BvA en VEA, Amsterdam.

Knox, S., and Bickerton, D. (2003) "The six conventions of corporate branding," European Journal of Marketing, Vol. 37, No. 7 \& 8, pp. 998-1016.

Kotler, P. (1986) “Megamarketing”, Harvard Business Review, (March-April): 117124.

Kotler, P., and Mindak, W. (1978) "Marketing and public relations, should they be partners or rivals?" Journal of Marketing, Vol. 42, No. 16, pp. 13-20.

Larcon, J.P., and Reitter, R. (1979) Structures de Pouvoir et Identite de L'Enterprise, Paris, Nathan.

Lawer, C., and Knox. S. (2008) "Reverse market orientation and corporate brand development", International Studies of Management and Organization, Vol. 37, No.4, pp. 64-83.

Leitch, S., and Devenport, S. (2008) "Corporate brands and social brands", International Studies of Management and Organization, Vol, 37, No.4, pp. 45-63.

Leitch, S., and Motion J. (1999) "Multiplicity in corporate identity strategy", Special Edition on Corporate Identity: Corporate Communications: An International Journal, Vol. 4, No.4, pp.193-199. 
Leitch, S., and Richardson, N. (2003) "Corporate branding in the new economy", European Journal of Marketing, Vol. 37, No.7 \& 8, pp. 1065-1079.

Lippincott. J.G., and Margulies, W.P. (1957) “The corporate look: a problem in design", Public Relations Journal, Vol. 13, pp. 4-6.

Mackenzie, J.M. (ed) (2001) The Victorian Vision. Inventing New Britain, V\&A Publications (Victoria and Albert Museum), London.

Marchand, R. (1991) "The corporation nobody knew: Bruce Barton, Alfred Sloan, and the founding of the General Motors 'Family' ". Business History Review, Vol. 65 , pp.825-875.

Margulies, W. (1977) "Make the most of your corporate image", Harvard Business Review (July-August), pp.66-77.

Martineau, P. (1958) "The personality of the retail store", Harvard Business Review, January-February, pp. 47-55.

Martineau, P. (1958a) "Sharper focus for the corporate image", Harvard Business Review, (November-December), pp. 49-58.

Marwick. N., and Fill, C. (1997) “Towards a framework for managing corporate identity", European Journal of Marketing, Vol.31, No.5 and 6, pp.396-409.

McClure, S., Li, J., Tomlin, D., Cypert, K.S., Montague, L.M., and Montague P.R. (2004) "Neural correlates of behavioral preference for culturally familiar drinks", Neuron, Vol. 44, October. pp.379-387.

Meffert, H. (1979) Praxis des Kommunikationsmix, BDW, Munster.

Melewar, T.C. (2008) Facets of Corporate Identity, Communication and Reputation, Routledge, London.

Melewar, T.C. (2001)"Measuring visual identity: a multi-construct study", Corporate Communications: An International Journal, Vol. 5, No. 1, pp. 36-41. 
Melewar, T.C., and Karaosmanoglu, E. (2006) "Seven dimensions of corporate identity: a categorization from practitioners' perspectives", European Journal of Marketing, Vol. 40, No. 7 and 8, pp. 846-869.

Melewar, T.C., and Harold, J. (1999) "The role of corporate identity in merger and acquisition activity", Journal of General Management, Vol. 26, No. 2, pp. 17-31.

Melewar, T.C., Saunders, J., and Balmer, J.M.T. (2001) "Cause, effect and benefits of a standardised corporate visual identity system of UK companies operating in Malaysia", Special Edition on Corporate Identity: European Journal of Marketing, Vol. 35, No.3 and4, pp. 414-427.

Melewar, T.C., Saunders. J., and Balmer, J.M.T. (2000) “The saliency of Olins' visual identity structure in relation to UK companies operating in Malaysia", Corporate Reputation Review, Vol. 3, No. 3, pp.194-200.

Merrilees, B., and Miller, D. (2008) "Principles of corporate rebranding", European Journal of Marketing, Vol. 42, No. 5\&6, pp. 537-552.

Mitchell, R.K., Agle, B.R.M., and Wood, D.J. (1997) “Toward a theory of stakeholder identification and salience: defining the principle of who and what really counts", Academy of Management Review, Vol. 22, No.4, pp. 853-886.

Moingeon, B., and Soenen, G. (2002) (eds) Corporate and Organizational Identities, London, Routledge.

Mukherjee, A., and Balmer, J.M.T. (2008) "New frontiers and perspectives in corporate brand management: in search of a theory", International Studies of Management and Organization, Vol. 37, No.4, pp. 3-19

Napoles, V. (1988) Corporate Identity Design. John Wiley and Son, New York.

Ohnemus, L., and Jenster, P. V. (2008) "Corporate brand thrust and financial performance", International Studies of Management and Organization, Vol.37, No.4, pp. 84-107.

Olins, W. (1991) "Corporate identity and the behavioural dimension", Design Management Review, Vol. 2, No.1. (Winter).

Olins, W. (1978) The Corporate Personality: An Inquiry into the Nature of 
Corporate Identity, Design Council, London.

Olins, W. (1978a) "Corporate identity: the myth and the reality," Lecture Delivered on December 6, 1978 to the Fellows and Members of the Royal Society for the Encouragement of Arts, Manufacturers and Trades in London, In Balmer J.M.T., and Greyser, S.A. (eds) (2003) Revealing the Corporation: Perspectives on corporate identity, image, reputation, corporate branding and corporate level marketing, Routledge, London, pp.54-65.

Oliver, T. (1986) The Real Coke, the Real Story, Penguin Books, New York.

Pilditch, J. (1971) Communication by Design: A Study in Corporate Identity, Maidenhead, UK: McGraw Hill.

Pratt, M.G. (1998) "To Be or Not to Be? Central Questions in Organizational Identification." In D. Whetten and P. Godfrey (1998) (eds) Identity in Organizations: Developing Theory Through Conversations, Thousand Oaks, CA: Sage, pp. 171-207.

Riley, J.W. (ed) (1963) The Corporation and its Publics. Essays on the Corporate Image, John Wiley and Son, New York.

Schafhauser, P. (1967) "How to keep your company image", Public Relations Journal, October, p.52.

Schultz, D.E., Tannenbaum, S.I. and Lauterborn, R.F. (1993) The New Marketing Paradigm: Integrated Marketing Communications, NTC, Lincolnwood, IL.

Schultz, M., and Hatch, M.J. (2003) "The cycles of corporate branding: the case of the Lego company", California Management Review, Vol. 46, No. 1, pp. 6-26.

Selame, E., and Selame, J. (1975) The Company Image, New York, John Wiley.

Simoes, C., Dibb, S., and Fisk, R. P. (2005) "Managing corporate identity: an internal perspective", Journal of the Academy of Marketing Science, Vol. 33, No. 2, pp. 153-168.

Skapinker, M. (2005) "How to hit the target in five easy steps", Financial Times, May 23, p. 8. 
Spector, A. J. (1961) "Basic dimensions of the corporate image", Journal of Marketing, Vol. 25, pp. 47-51.

Stuart, H. (1999) “Towards a definitive model of the corporate identity management process", Special Edition on Corporate Identity: Corporate Communications: An International Journal, Vol. 4, No. 4, pp. 200-207.

Taguiri, R. (1982) "Managing corporate identity: the Role of Top Management", International Seminar on Corporate Identity Building, CERAM, Sophia Antipolis, France.

Tajfel, H. (1972) "La categorization sociale", In. Moscovici. S. (ed) Introduction a la Psychologie Sociale, Vol. 1, pp. 272-302.

Tajfel, H., and Turner, J.C. (1979) "An integrative theory of group conflict", In Austin, W.G. and Worchel, S. (eds) The Social Psychology of Intergroup Relations, Brooks/Cole, Monterey, CA. pp.7-24.

Topalian, A. (1984) "Corporate identity: beyond the visual overstatements," International Journal of Advertising, Vol. 3, pp. 55-62.

Urde, M. (2003) "Core based corporate brand building", European Journal of Marketing, Vol. 37, No. 7 \& 8, pp. 1017-1040.

Urde, M., Greyser, S.A., and Balmer, J.M.T, (2007) "Brands with a heritage", Journal of Brand Management, Vol. 15, No.1, pp. 4-19.

Van Riel, C.B.M. (1995) Principles of Corporate Communications, Prentice Hall, London.

Van Riel, C.B.M., and Balmer, J.M.T. (1997) "Corporate identity: the concept, its measurement and management", European Journal of Marketing, Vol. 31, pp. 340356.

Wilkinson, A., and Balmer, J.M.T., (1996) "Corporate and generic identities: lessons from the Co-operative bank", International Journal of Bank Marketing, Vol. 14, No. 4, pp. 22-35. 
Worcester, Robert Sir. (1997) "Managing the image of your bank; the glue that binds", Special Edition on Corporate Identity in Financial Services: International Journal of Bank Marketing, Vol. 15, No. 5, pp. 146-152.

Worcester, Robert Sir. (1986) "Corporate image" , In Worcester, R., and Downham. J. (eds) The Consumer Marketing Research Handbook, McGraw-Hill, London.

\section{Acknowledgements}

The author is indebted to my good friend and colleague Professor Greyser of Harvard Business School for his generosity of spirit in kindly reading this manuscript and in making a number of suggestions. I am also grateful to my faculty colleagues at Brunel University, London for their continued support and encouragement.

\section{About the author}

Professor John M.T. Balmer is the Founder, Chairman and Conference Organiser of the International Corporate Identity Group (ICIG). The first symposium took place in 1994 and the ICIG was formally launched in the House of Lords, Palace of Westminster, in 1995. He has single-handedly organised nine of the ICG symposia and has jointly organised the other two. Speakers at former ICIG symposia have included prominent politicians (Lord Mandelson: current UK Secretary of State for Business and former EU Commissioner for trade), captains of industry including Lord Browne (former Group CEO of BP), Lord Marshall of Knightsbridge (Chairman of Nomura International, Chairman of Pirelli UK and former CEO of British Airways), Andrew Buxton (the Chairman of Barclays Bank), David Anderson (CEO of the Yorkshire Building Society and currently CEO of the Co-operative Bank) and Lord King of Wartnaby (President of British Airways), leading consultants of corporate marketing (Professor Sir Robert Worcester, Wally Olins CBE, David Bernstein, Clive Chajet and Ardian Day etc) and eminent academics (Professor Stephen A. Greyser, Professor John Kay, Professor Mary Jo Hatch, Professor Maijken Schultz, Professor Cees van Riel, Professor Denis Bromley etc).

He has been a leading proponent of the strategic importance of corporate identity, corporate branding and corporate marketing to scholars and practitioners alike and has been tireless in his advocacy of these areas over the last two decades. Since 1997 he has served as guest editor for over 13 special editions of academic journals on the above areas. He has written many landmark articles on corporate identity, corporate branding and corporate marketing in leading journals including California Management Review, European Journal of 
Marketing, Long Range Planning, Journal of Business Ethics and the British Journal of Management.

Currently, Professor Balmer is Professor of Corporate Marketing at Brunel University, London where he is the Director of the MSc in Corporate Brand Management. He was quondam Professor of Corporate Identity and Bradford School of Management and then Professor of Corporate Identity/Brand Management at the same institution. It is believed the Chairs held by him are the first of their kind. At Strathclyde Business School, Glasgow, he was Founder/Director of the International Centre for Corporate Identity Studies and it was during his time as a member of the faculty at the school that he founded the ICIG.

He conceived and developed the MBA, MSc and BA (Honours) electives in corporate identity/corporate branding and corporate marketing at Strathclyde Business School and at Bradford School of Management. The first of these courses ran in 1991: these courses are believed to be the first of their kind. He has also run executive-level MBA electives on these areas for senior managers at the $\mathrm{BBC}$ and for Emirates Airways among others.

With Professor Stephen A. Greyser he is the author of the seminal text "Revealing the Corporation" which examines corporate marketing along with the corporatelevel constructs of corporate identity, corporate branding, corporate communications and corporate reputation (Routledge, 2003). He has worked with a variety of organisations on research projects in corporate marketing, including the BBC, WPP Group and, notably, the Swedish Monarchy.

Before joining academe he worked in Arts and Theatre Administration and was Assistant Administrator of Lord Menuhin's Live Music Now Concert Agency in London. He was subsequently appointed a member of the senior management team at the Dome Complex, Royal Pavilion Estate, Brighton. He is a graduate of the Universities of Reading, Durham and Strathclyde. 